\title{
PENERAPAN MODEL PEMBELAJARAN INKUIRI TERBIMBING UNTUK MENINGKATKAN HASIL BELAJAR SISWA DI KELAS XII IPA-2 SMA NEGERI 1 BAGAN SINEMBAH KAB. ROKAN HILIR
}

\author{
Dalima Siregar \\ Surel: dalimaharlan@gmail.com
}

\begin{abstract}
The purpose of this study was to determine the improvement of science process skills and student learning outcomes after the application of a guided curriculum learning model in class XII IPA-2 State Senior High School 1 Bagan Sinembah District. Rokan Hilir. This research was carried out in the classroom including classroom action activities $(P T K)$ in the form of initial reflection activities and conducting observations to identify problems that occur in the classroom, planning learning, implementing actions, observation and reflection. The findings of this CAR are: 1) Increased learning outcomes from the complete cycle I as many as 24 people or $72.7 \%$ to as many as 29 people who completed or $87.9 \%$; 2) Improving science process skills from cycle I from 5 groups from 4 aspects assessed by 3 aspects, namely observing, collecting data and concluding still in sufficient category while in communicating aspect it is in good category.
\end{abstract}

Keywords: Models, Guided Inquiry, Science Process Skills

\begin{abstract}
ABSTRAK
Tujuan penelitian ini adalah untuk mengetahui peningkatan keterampilan proses sains dan hasil belajar siswa setelah penerapan model pembelajaran ikuiri terbimbing di kelas XII IPA-2 SMA Negeri 1 Bagan Sinembah Kab. Rokan Hilir. Penelitian ini dilaksanakan dalam kelas meliputi kegiatan pelaksanaan tindakan kelas (PTK) berupa kegiatan refleksi awal dan melakukan observasi untuk mengidentifikasi permasalahan yang terjadi di kelas, perencanaan pembelajaran, pelaksanaan tindakan, observasi dan refleksi. Adapun temuan penelitian PTK ini adalah; 1) Peningkatan hasil belajar dari siklus I yang tuntas sebanyak 24 orang atau $72,7 \%$ menjadi sebanyak 29 orang yang tuntas atau 87,9\%; 2) Peningkatan keterampilan proses sains dari siklus I dari 5 kelompok dari 4 aspek yang dinilai 3 aspek yaitu mengamati, mengumpulkan data dan menyimpulkan masih dalam kategori cukup sedangkan pada aspek mengkomunikasikan sudah masuk kategori baik.
\end{abstract}

Kata Kunci: Model, Inkuiri Terbimbing, Keterampilan Proses Sains

\section{PENDAHULUAN}

Keterampilan Proses Sains

(KPS) adalah keterampilan yang melibatkan keterampilan-

keterampilan kognitif atau intelektual, manual dan sosial. Keterampilan kognitif terlibat karena dengan melakukan keterampilan proses siswa menggunakan pikirannya. Keterampilan proses sains sangat penting dimiliki oleh siswa untuk menghadapi persaingan di era globalisasi yang menuntut persaingan antarmanusia. Nandang (2009) 
mengutarakan bahwa era globalisasi yang berlangsung menuntut siswa untuk dapat menyelesaikan masalah yang bersifat spesifik dan juga mampu mengoptimalkan kemampuan kognitif (cognitive tools) serta berbagai kompetensi lainnya. Sehubungan dengan hal tersebut, Dahar (1996), keterampilan proses sains (KPS) adalah kemampuan siswa untuk menerapkan metode ilmiah dalam memahami, mengembangkan dan menemukan ilmu pengetahuan. KPS sangat penting bagi setiap siswa sebagai bekal untuk menggunakan metode ilmiah dalam mengembangkan sains serta diharapkan memperoleh pengetahuan baru atau mengembangkan pengetahuan yang telah dimilik

Selain itu, beberapa alasan yang yang melandasi perlunya keterampilan proses dalam kegiatan belajar mengajar dikemukakan oleh Semiawan, dkk (2002) bahwa siswa lebih mudah memahami konsep rumit dan abstrak jika disertai dengan contoh konkret atau melalui benda nyata, sehingga siswa belajar secara aktif dan kreatif dalam mengembangkan keterampilan untuk memproseskan perolehan konsep. Lebih lanjut Semiawan, dkk (2002) juga mengungkapkan bahwa keterampilan proses sains sangat penting diterapkan dalam proses belajar mengajar agar anak dapat berlatih untuk selalu bertanya, berpikir kritis, menumbuh kembangkan keterampilan fisik dan mental, serta sebagai wahana untuk menyatukan pengembangan konsep siswa dengan pengembangan sikap dan nilai yang penting sebagai bekal terhadap tantangan di era globalisasi. Meskipun demikian, kenyataan di dunia pendidikan keterampilan proses sains belum dikembangkan secara optimal khususnya di SMA Negeri 1 Bagan Sinembah Kab. Rokan Hilir Provinsi Riau pada tahun Pelajaran 2015/2016. Kurangnya penerapan KPS khsusunya pada mata pelajaran biologi dikarenakan guru kurang memahami langkah-langkah ketampilan proses sains yang diaplikasikan dalam pembelajaran maupun dalam praktikum. Pengembangan keterampilan proses sains baik dalam proses pembelajaran maupun evaluasi hasil belajar sangat jarang dilakukan, sehingga siswa kurang mampu mengembangkan keterampilan dalam menemukan dan menghubungkan konsep yang disampaikan.

Dilihat dari hasil belajar biologi pada semester 1 juga menunjukkan sekitar $60 \%$ siswa tidak tuntas Kriteria Ketentasan Minimal (KKM) yang ditetapkan yaitu 60, sehingga guru melakukan remedial dalam proses belajar mengajar. Mengingat pentingnya keterampilan tersebut. Menurut Blosser (1973), proses pembelajaran sains cenderung menekankan pada pemberian pengalaman langsung untuk mengembangkan kompetensi dan menumbuhkan kemampuan berfikir. Pembentukan sikap ilmiah seperti ditunjukan oleh para ilmuwan sains dapat dikembangkan melalui keterampilan-keterampilan proses sains. Sehingga keterampilan proses 
sains, dapat digunakan sebagai pendekatan dalam pembelajaran.

$\begin{array}{rcr}\text { Maka } & \text { diperlukan model } \\ \text { pembelajaran } & \text { yang } & \text { dapat } \\ \text { memfasilitasi } & \text { terselenggaranya }\end{array}$
kegiatan pembelajaran yang mampu mengembangkan keterampilan proses sains siswa. Salah satu model pembelajaran yang diharapkan dapat mengembangkan keterampilan proses sains siswa adalah pembelajaran dengan menggunakan model pembelajaran inkuiri terbimbing (guided inquiry).

Sedangan menurut Hamruni (2012) menyatakan sebagai berikut: 1) Menekankan kepada aktivitas siswa untuk mencari dan menemukan; 2) Aktivitas belajar siswa diarahkan untuk mencari dan menemukan sendiri jawaban dari sesuatu yang dipertanyakan sehingga dapat menumbuhkan sikap percaya diri (self belief); 3) Mengembangkan kemampuan berfikir secara sistematis, logis dan kritis.

Dari latar belakang masalah diatas, tujuan dari penelitian tindakan kelas ini adalah: 1) Memberikan gambaran tentang rencana pelaksanaan pembelajaran yang disusun dengan menggunakan model inkuiri terbimbing; 2) Untuk mengetahui peningkatan keterampilan proses sains siswa setelah penerapan model pembelajaran ikuiri terbimbing di kelas XII IPA-2 SMA Negeri 1 Bagan Sinembah Kab. Rokan Hilir; 3) Untuk mengetahui peningkatan hasil belajar siswa setelah penerapan model pembelajaran ikuiri terbimbing di kelas XII IPA-2 SMA Negeri 1 Bagan Sinembah Kab. Rokan Hilir.

\section{METODE PENELITIAN}

Penerapan

model pembelajaran ini menurut, Ibrahim dalam Paidi (2007) menerangkan guide inkuiry/Inkuiri terbimbing sebagai kegiatan dimana peserta didik diberikan kesempatan untuk bekerja merumuskan prosedur, menganalisis hasil, dan mengambil kesimpulan secara mandiri, sedangkan dalam hal menentukan topik, pertanyaan, dan bahan penunjang, guru hanya sebagai fasilitator.

Model pembelajaran inkuiri terbimbing merupakan posisi guru membimbing siswa dengan melakukan kegiatan dengan memberi pertanyaan awal dan mengarahkan pada suatu diskusi. Guru mempunyai peran aktif dalam menentukan permasalahan dan tahap-tahap pemecahannya. Dalam model pembelajaran ikuiri terbimbing siswa tidak hanya mencari dan menemukan pengetahuan sebagai solusi untuk memecahkan masalah tetpi siswa juga dapat memahami pembelajaran sehingga tercipta kegiatan yang variatif sehingga dapat memotivasi siswa.

\section{HASIL PENELITIAN DAN PEMBAHASAN}

Jenis penelitian ini adalah Penelitian Tindakan Kelas (PTK) atau Classroom Action Research (CAR). PTK ialah kajian tentang situasi sosial dengan maksud untuk meningkatkan kualitas tindakan di dalamnya (Elliot, 1982). Seluruh prosesnya, telaah, diagnosis, perencanaan, pelaksanaan, pemantauan, dan pengaruh menciptakan hubungan yang 
diperlukan antara evaluasi diri dari perkembangan profesional. Pendapat yang hampir senada dikemukakan oleh Kemmis dan Mc Taggart, yang mengatakan bahwa PTK adalah suatu bentuk refleksi diri kolektif yang dilakukan oleh peserta-pesertanya dalam situasi sosial untuk meningkatkan penalaran dan keadilan praktik-praktik itu dan terhadap situasi tempat dilakukan praktikpraktik tersebut (Kemmis dan Taggart, 1988).

\section{Siklus I}

$\begin{array}{rrr}\text { Proses } & \text { belajar } & \text { mengajar } \\ \text { menggunakan } & \text { model } & \text { inkuiri }\end{array}$ terbimbing yang dilakukan pada materi Bioteknologi di kelas XII IPA2 SMA Negeri I bagan Sinembah dengan Kriteria Ketuntasan Minimal Mata pelajaran Biologi $(\mathrm{KKM}=70)$ diperoleh hasil belajar siswa tertera pada gambar 1 dibawah ini.

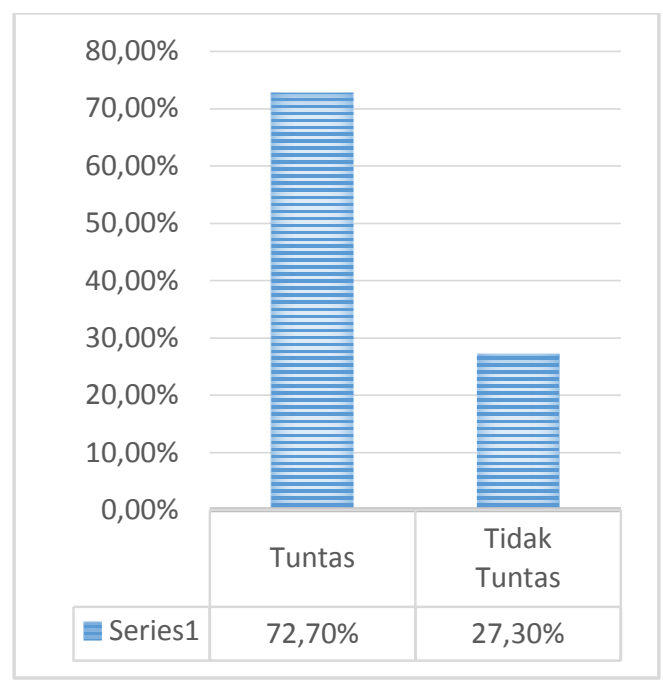

Gambar 1. Hasil Belajar Siklus I

Dari gambar diatas diperoleh hasil belajar biologi kelas XII IPA-2 SMA Negeri 1 Bagan Sinembah, dapat ditarik kesimpulan bahwa pembelajaran dengan menggunakan model pembelajaran Inkuiri terbimbing untuk meningkatkan hasil belajar dari 33 orang siswa diperoleh 24 orang yang tuntas dengan $72,7 \%$ dan 9 orang yang tidak tuntas dengan $27,3 \%$.

\section{Siklus II}

Perencanaan siklus II berdasarkan kendala dan kelemahan yang ditemukan pada siklus I dan dari hasil observasi keterampilan proses sains siswa dalam penerapan model pembelajaran inkuiri terbimbing, agar kendala dan kelemahan pada siklus I tidak terjadi lagi maka guru berupaya semaksimal mungkin untuk mengontrol kegiatan proses belajar mengajar dan memberikan motivasi kepada siswa. Hasil belajar siswa tertera pada gambar 2 dibawah ini.

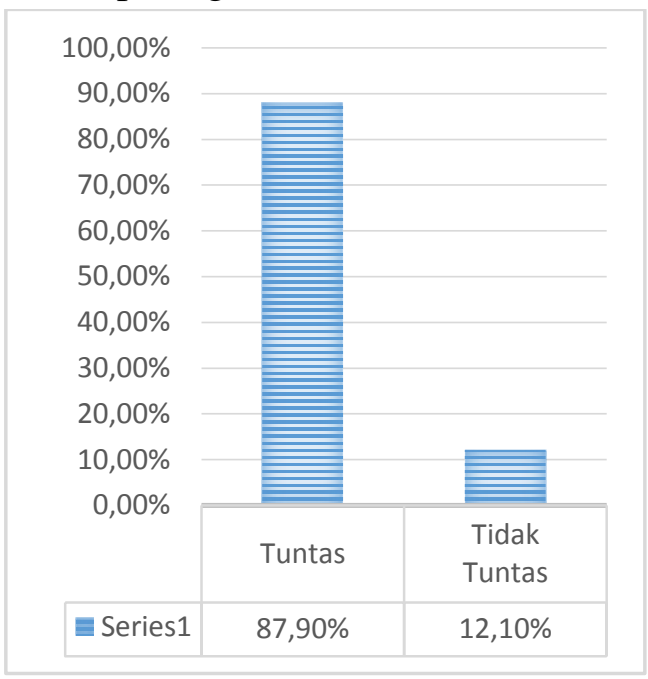

\section{Gambar 2. Hasil Belajar Siklus I}

Dari gambar 2 diatas diperoleh hasil belajar biologi kelas XII IPA-2 SMA Negeri 1 Bagan Sinembah Tahun Pelajaran 2015/2016, dapat ditarik kesimpulan bahwa pembelajaran dengan 
Dalima Siregar : Penerapan Model Pembelajaran ...

menggunakan model pembelajaran Inkuiri terbimbing untuk meningkatkan hasil belajar dari 33 orang siswa diperoleh 29 orang yang tuntas dengan $87,9 \%$ dan 4 orang yang tidak tuntas dengan $12,1 \%$. Secara ketuntasan klasikal pada siklus II ini diketahui bahwa kelas XII IPA2 telah mengalami ketuntasan klasikal karena telah melewati $85 \%$ sesuai pendapat Asnita, 2013 mengatakan interval daya serap klasikal $85 \%$ tergolong tinggi.

\section{Pembahasan}

Hasil penelitian tindakan kelas yang dilakukan di SMA Negeri 1 Bagan Sinembah Kab. Rokan Hilir TP. 2015/2016 diperoleh hasil pada siklus I dari 33 orang siswa diperoleh 24 orang yang tuntas dengan $72,7 \%$ dan 9 orang yang tidak tuntas dengan 27,3\%. Dan keterampilan proses sains diperoleh dari 5 kelompok dari 4 aspek yang dinilai 3 aspek yaitu mengamati, mengumpulkan data dan menyimpulkan masih dalam kategori cukup sedangkan pada aspek mengkomunikasikan sudah masuk kategori baik. Pada siklus I ini dilihat dari ketuntasan klasikal belum terpenuhi hasil observasi ditemukan bahwa siswa belum terbiasa menerapkan model pembelajaran inkuiri untuk meningkatkan keterampilan proses, hal ini selajan dengan pendapat Simatupang, $H$. 2014 yang mengatakan keterampilan proses harus benar-benar melibatkan peserta didik dalam prosesnya.

Pada siklus II hasil belajar diperoleh 33 orang siswa diperoleh 29 orang yang tuntas dengan $87,9 \%$ dan
4 orang yang tidak tuntas dengan 12,1\%. Dan hasil observasi keterampilan proses sains diperoleh dari 5 kelompok dari 4 aspek yang dinilai 2 aspek yaitu memiliki kategori sangat baik yaitu aspek mengamati dan aspek mengkomunikasikan, 2 aspek memiliki kategori baik yaitu aspek menganalisis data dan aspek mengkomunikasikan.

Hasil analisis peningkatan hasil belajar dari siklus I yang tuntas sebanyak 24 orang atau $72,7 \%$ menjadi sebanyak 29 orang yang tuntas atau $87,9 \%$, peningkatan hasil belajar ini diperoleh karena proses belajar mengajar berlangsung membantu siswa dalam mengembangkan konsep belajar. Menggunakan model pembelajaran inkuiri terbimbing yang merupakan pembelajaran yang menggunakan pendekatan ilmiah. Dari penggabungan dua konsep antara keterampilan proses sains siswa dengan model penbelajaran inkuiri terbimbing, siswa berperan secara langsung baik secara individu maupun kelompok untuk menggali konsep dan prinsip selama kegiatan pembelajaran, sedangkan tugas guru adalah mengarahkan proses belajar yang dilakukan siswa dan memberikan koreksi terhadap konsep dan prinsip yang didapatkan siswa. Dapat ditarik kesimpulan bahwa model pembelajaran inkuiri dapat meningkatkan hasil belajar biologi sejalan dengan hasil penelitian ini didukung hasil penelitian Setiawan (2005); Winarni (2006). Kedua penelitian ini menunjukkan bahwa 
penerapan pembelajaran dengan metode inkuiri terbimbing dapat meningkatkan pemahaman konsep dan hasil belajar kognitif siswa. Keterlibatan aktif siswa dalam belajar akan meningkatkan hasil belajarnya Hasil analisis keterampilan proses sains dari siklus I dari 5 kelompok dari 4 aspek yang dinilai 3 aspek yaitu mengamati, mengumpulkan data dan menyimpulkan masih dalam kategori cukup sedangkan pada aspek mengkomunikasikan sudah masuk kategori baik.

\section{SIMPULAN}

Berdasarkan temuan hasil penelitian dengan judul "Penerapan Model Pembelajaran Inkuiri Terbimbing Untuk Meningkatkan Keterampilan Proses Sains dan Hasil Belajar Siswa Di Kelas XII IPA-2 SMA Negeri 1 Bagan Sinembah Kab. Rokan Hilir", dapat ditarik kesimpulan sebagai berikut :

a. Peningkatan hasil belajar dari siklus I yang tuntas sebanyak 24 orang atau $72,7 \%$ menjadi sebanyak 29 orang yang tuntas atau $87,9 \%$.

b. Peningkatan keterampilan proses sains dari siklus I dari 5 kelompok dari 4 aspek yang dinilai 3 aspek yaitu mengamati, mengumpulkan data dan menyimpulkan masih dalam kategori cukup sedangkan pada aspek mengkomunikasikan sudah masuk kategori baik. Meningkat pada siklus II menjadi dari 5 kelompok dari 4 aspek yang dinilai 2 aspek yaitu memiliki kategori sangat baik yaitu aspek mengamati dan aspek mengkomunikasikan, 2 aspek memiliki kategori baik yaitu aspek menganalisis data dan aspek mengkomunikasikan.

\section{DAFTAR RUJUKAN}

Hamruni. 2012. Strategi Pembelajaran. Yogyakarta: Insan Madani.

Hamiyah, N. Dan M. Jauhar. 2014. Strategi Belajar-Mengajar di Kelas. Jakarta: Prestasi Pustaka.

Hanafiah, Nanang. dan Cucu, Suhana. 2009. Konsep Strategi Pembelajaran. Bandung: PT Refika Aditama.

Komalasari, Kokom. 2011. Pembelajaran kontekstual konsep dan. Aplikasi. Bandung: PT Refika Aditama

Nandang, Rusmana. 2009. Pemarinan (game \& Play). Bandung: Rizky Press

Ngalimun. 2012. Strategi dan Model Pembelajaran. Banjarmasin:: Aswaja Pressindo.

Simatupang, H. 2014. Peningkatan Kerja Ilmiah Dalam Praktikum Biologi Dengan Keterampilan Proses Mahasiswa Semester Jurusan Biologi Universitas Negeri Medan. Medan: Prosiding Seminar Nasional Biologi dan Pembelajarannya Medan, 23 Agustus 2014. 